\title{
Evaluasi Pembelajaran Terintegrasi
}

\author{
Sawaluddin \\ Sekolah Tinggi Agama Islam Rokan Bagan Batu Rokan Hilir \\ Email: regarsawaluddin@gmail.com
}

\begin{abstract}
Tujuan Penelitian ini adalah untuk menganalisi Evaluasi Pembelajaran Terintegrasi, Prinsip Dasar Evaluasi Pembelajaran Terintegrasi. Ciri-ciri Evaluasi Pembelajaran Terintegrasi dan Ranah Evaluasi Pembelajaran Terintegrasi. Penelitian ini lakukan untuk mengkaji tentang Distingsi Evaluasi Pembelajaran Terintegrasi. Penelitian bersifat kualitatif dengan dengan menganalisi beberapa buku literatur dan sebagai sumber data utama. Adapun Hasil Penelitian ini dapat disimpulkan bahwa Evaluasi Pembelajaran Terintegrasi merupakan kegiatan untuk menilai sesuatu secara terencana, sistematik, dan terarah berdasarkan tujuan yang jelas dengan menggabungkan sejumlah disiplin keilmuan melalui penentuan isi (content), kemampuan, dan tujuan afektif. Adapun Prinsip Dasar Evaluasi Pembelajaran Terintegrasi, yaitu keterpaduan, keterampilan siswa, koherensi, pedagogis, dan akuntabilitas. Sedangkan Ciri-ciri Evaluasi Pembelajaran Terintegrasi yaitu, Evaluasi dilakukan dalam rangka mengukur keberhasilan belajar siswa, di mana pengukurannya dilakukan secara tidak langsung. Sementara Ranah Evaluasi Pembelajaran Terintegrasi, yakni aspek kognitif, aspek afektif dan aspek psikomotor.
\end{abstract}

Key Words: Evaluasi; Pembelajaran; Terintegrasi

\section{PENDAHULUAN}

Pembelajaran adalah upaya sadar dan tanggung jawab untuk memelihara ,membimbing dan mengarah kan pertumbuhan dan perkembangan kehidupan peserta didik agar ia memiliki makna dan tujuan hidup yang hakiki. Sementara proses Pembelajaran bertujuan untuk menimbulkan perubahan -perubahan yang diinginkan pada setiap peserta didik.

Tujuan pokok proses pembelajaran adalah untuk mengubah tingkahlaku siswa berdasarkan tujuan yang telah direncanakan dan disusun oleh guru sebelum proses kegiatan pembelajaran berlangsung. Perubahan tingkah laku itu mencakup aspek intelektual. Untuk menghasilkan dan mengetahui daya serap siswa terhadap pembelajaran yang dilakukan dan untuk mengetahui perubahan tingkah lakunya, maka evaluasi adalah salah hal yang sangat urgen untuk dilakukan. Sebab Evaluasi dipandang sebagai masukan yang diperoleh dari proses pembelajaran yang dapat dipergunakan untuk mengetahui kekuatan dan kelemahan berbagai komponen yang terdapat dalam suatu proses belajar mengajar (Sawaluddin, 2018).

Perubahan perubahan yang diinginkan pada peserta didik meliputi tiga bidang yaitu (1) tujuan yang personal dan yang berkaitan dengan individuindividu yang sedang belajar untuk terjadinya perubahan yang diinginkan, baik perubahan tingkah laku, aktivitas dan pencapainya, serta pertumbuhan yang diingini pada peserta didik (2) tujuan sosial yang berkaitan dengan kehidupan masyarakat sebagai unit sosial berikut dengan dinamika masyarakat umumnya (3) tujuan profesional yang berkaitan dengan Pembelajaran dan pengajaran sebagai ilmu, seni dan profesi. Proses Pembelajaran yang dimaksud tidak terlepas dari beberapa komponen yang mendukung. Salah satu nya komponen yang urgen dalam melihat keberhasilan Pembelajaran adalah evaluasi (Sawaluddin, Koy Sahbudin Harahap, 
Supardi Ritonga, Muhammad Ramli, 2020).

Evaluasi belajar dan pembelajaran sangatlah penting utamanya di dunia Pembelajaran. Hal ini dikarenakan evaluasi digunakan untuk mengetahui sejauh mana tingkat pencapaian peserta didik dalam menempuh mata pelajaran yang telah disajikan. Sehingga untuk mengetahui apakah tujuan pembelajaran yang telah dirumuskan dapat tercapai, apakah aktivitas yang dilakukan telah berhasil mencapai sasaran, apakah prosedur kerja yang dilakukan sudah tepat, apakah sumber daya yang dimiliki sudah dapat dimobilisasi secara optimal untuk mencapai tujuan, dan apakah elemen-elemen pendukung kegiatan sudah berfungsi dengan baik, digunakan suatu evaluasi untuk semua hal tersebut. Peran evaluasi merupakan hal yang sangat penting dan keberadaannya tidak dapat tergantikan. Dengan adanya evaluasi seorang pengajar akan mampu melihat perkembangan dari setiap peserta didiknya dan dapat melakukan tindakan lebih lanjut manakala peserta didiknya mengalami kemunduran dalam pencapaian hasil belajar atau peserta didik belum mampu mencapai prestasi yang optimal (Sawaluddin, dan Muhammad Siddiq, 2020).

\section{METODE}

Penelitian ini lakukan untuk mengkaji tentang Evaluasi Pembelajaran Terintegrasi. Penelitian bersifat kualitatif dengan dengan menganalisi beberapa buku literatur dan sebagai sumber data utama.

\section{Hasil dan Pembahasan}

\section{Evaluasi Pembelajaran Terintegrasi}

Ada beberapa pengertian Pembela jaran terpadu yang dikemukakan oleh para ahli, pengertian tersebut adalah sebagai berikut:

a. Ollin dan Dixon Sebagaimana yang dikutip oleh Muh. Faisal, Ollin dan Dixon menjelaskan bahwa "Pembelajaran terpadu adalah pembelajaran yang terjadi ketika suatu peristiwa yang otentik atau pembahasan suatu topik merupakan penggerak utama dalam kurikulum. Melalui partisipasi secara aktif dalam pembahasan topik atau peristiwa, siswa dapat mempelajari baik proses maupun isi yang berkaitan dari berbagai bidang studi dalam waktu yang sama" (Muh. Faisal, 2001).

b. Frazee dan Rose Dikutip pula oleh Muh. Faisal, Frazee dan Rose memberikan definisi bahwa "Pembelajaran terpadu adalah pembelajaran yang dilaksanakan dengan menggabungkan sejumlah disiplin keilmuan melalui penentuan isi (content), kemampuan, dan tujuan afektif." (Muh. Faisal, 2001)

c. Menurut Muhammad Numan Soemantri "Pembelajaran terpadu adalah "keseluruhan mata pelajaran yang diharapkan dapat tumbuh secara simbiostik saling mempengaruhi dan memperkaya (Muhammad Numan Soemantri, 2001). Dalam artian adanya keterkaitan satu sama lain, sehingga masing-masing konsep selalu akan memberi kemudahan dan berakses luas terhadap upaya memperkuat cara berpikir intelektual sejalan dengan proses internalisasi nilai agama dan kebudayaan" (Muhammad Numan Soemantri, 2001)

d. Menurut Oemar Hamalik Pengajaran terpadu yaitu "pengajaran yang bersifat menyeluruh, yang memadukan berbagai disiplin pelajaran yang berpusat pada suatu masalah atau topik proyek, baik teoritis maupun praktis dan memadukan kelembagaan sekolah dan luar sekolah yang mengembangkan program terpadu berdasarkan kebutuhan siswa, kebutuhan masyarakat dan yang memadukan kegiatan belajar mengajar untuk mencapai tujuan pengembangan kepribadian siswa yang terintegrasi." (Oemar Hamalik, 2012). 
e. Moh. Kasiram Pembelajaran Terpadu adalah Pembelajaran yang utuh antara sains dan agama, keduanya diharapkan dapat berjalan secara berdampingan dan seimbang (Moh. Kasiram, 1999). Keterpaduan yang dimaksud oleh penulis dalam skripsi ini adalah terpadu dalam Pembelajaran agama dan umum (Nurcholis Madjid, 1992) atau dapat disebut pula sebagai perpaduan antara Pembelajaran tradisional dan Pembelajaran sekuler yang merupakan salah satu sistem Pembelajaran alternatif untuk menghilangkan dikotomi dalam sistem Pembelajaran yang dikemukakan para cendekiawan Islam sejak abad delapan belas dan awal abad sembilan belasan dan mengalami penyempurnaanpenyem purnaan sampai sekarang.

Sistem ini dirumuskan dengan tujuan untuk menggabungkan keutamaankeutamaan yang ada pada kedua sistem Pembelajaran yang sudah berlaku di kalangan kaum muslimin guna meningkatkan kualitas mereka di segala aspek kehidupan, khususnya kualitas intelektualitas yang menjadi sumber penggerak kemajuan (Hilmy Bakar Almascaty, 2000). Penggabungan ini pada hakikatnya berangkat dari asumsi bahwa sistem Pembelajaran tradisional telah terbukti melahirkan para cendekiawan yang memahami Islam dengan baik dan konsisten dalam melaksanakannya, namun kelemahan mereka tidak menguasai sains-sains modern dengan metode ilmiahnya, sementara sistem sekuler terbukti telah melahirkan para cendekiawan yang ulung dalam menguasai sains-sains modern dengan metodologinya, namun tidak memahami Islam dengan baik, bahkan cenderung tidak konsisten terhadap ajaran Islam akibat bias faham sekulerisme yang netral dari melahirkan model cendekiawan Muslim yang memahami ajaran Islam dengan baik serta konsisten dalam melaksanakannya sekaligus menguasai pengetahuan modern dengan metodeloginya sebagaimana cendekiawan Barat, dan mereka akan menjadi penggerak kemajuan kaum Muslimin dengan penguasaan sains-teknologi modern dan sekaligus mengembangkan sains-sains baru yang berlandaskan semangat Islam.

Oleh karena itu, para sarjana muslim harus bersatu menciptakan ajaran-ajaran mereka sendiri guna mengem bangkan ilmu sosial dan ilmu kemanusiaan lainnya. Di samping itu para pemikir muslim harus mampu menantang ilmuan Barat yang pikiranpikirannya dipenuhi hipotesis-hipotesis materialistik, yang menolak berlakunya kehendak Allah di muka bumi ini. Sebab bila tidak maka umat Islam akan sama permisifnya dengan masyarakat Barat. Sebaliknya bila umat Islam berani melangkah, maka secara optimis dikatakan umat Islam akan kembali menemukan sistem Pembelajaran Islam dalam bentuk utuhnya (Ikhrom, 2001). Umumnya para cendekiawan muslim yang menyerukan pembaharuan sistem Pembelajaran dengan menggabungkan kedua sistem ini memiliki asumsi-asumsi dasar yang mereka jadikan sebagai landasan teorinya, sebagaimana dikemukakan oleh Fazlur Rahman (1985):

1) Bahwa pemerolehan pengetahuan modern hanya dibatasi pada bidang teknologi praktis, karena pada bidang pemikiran murni kaum muslimin tidaklah memerlukan produk intelektual Barat, bahkan produk tersebut haruslah dihindari, karena mungkin sekali akan menimbulkan keraguan dan kekacauan dalam pikiran Muslim, di mana sistem kepercayaan Islam Tradisional telah memberikan jawaban-jawaban yang memuaskan bagi pertanyaan-pertanyaan puncak mengenai pandangan dunia.

2) Bahwa kaum muslimin tanpa takut boleh dan harus memperoleh tidak hanya teknologi Barat saja, tapi juga intelektualnya, karena tidak ada satu 
jenis pengetahuan pun yang merugikan dan bahwa bagaimanapun juga sains dan pemikiran-pemikiran murni dulu telah dengan giat dikembangkan kaum Muslimin pada awal abad-abad pertengahan, yang kemudian diambil alih oleh Eropa Sendiri.

Fazlur Rahman membagi proses pembaharuan yang akan menggabungkan kedua sistem Pembelajaran ini, yang diistilahkannya sebagai modernisasi, menjadi dua fase, yaitu: 1). Modernisasi Klasik (Classical modernism), 2). Modernisasi Kontemporer (Contemporary Modernism) (Fazlur Rahman, 1985). Pada fase modernisasi klasik ditandai dengan munculnya cendekiawan muslim yang ingin memperbaharui (memodernisasikan) sistem tradisional yang diterapkan lembaga Pembelajaran tradisional sejak abad pertengahan lalu dengan memasukkan sains-sains modern yang diadopsi dari Barat ke dalam kurikulum yang sudah ada (Sawaluddin, Sainab, 2019).

Pada fase ini dinyatakan gagal karena tidak adanya tenaga pengajar profesional yang memahami benar orientasi sistem gabungan ini, namun masih tetap diadakan penyempurnaanpenyempurnaan. Fase modernisasi kontemporer sudah berada di alam kemedekaan, di mana kaum Muslimin sudah memiliki kebebasan untuk menentukan pilihannya sendiri, sistem apakah yang akan dipergunakan dalam Pembelajarannya tanpa harus ditekan dan didekte penjajah yang memiliki budaya yang berbeda. Sistem Pembelajaran gabungan ini terus menerus diadakan penyempurnaan. Demikian pula halnya dengan universitas-universitas tradisional seperti Al-Azhar berlomba-lomba mengadakan pembaharuan dalam metode dan sistem Pembelajaran agar tidak ketinggalan zaman (Hilmy Bakar Almascaty, 2000).
Namun sampai sejauh ini para cendekiawan muslim belum berhasil merumuskan sistem Pembelajaran Islam secara terperinci dan sistematis dalam pedoman pelaksanaan, kecuali masih dalam taraf pengujian teori-teori yang lalu ataupun yang baru dikemukakan para cendekiawan muslim. Dan harus diakui, penyempurnaan dan pengembangan sistem Pembelajaran memerlukan waktu yang panjang, ia harus melalui tahaptahap pengujian teori dan praktik di lapangan sehingga menjadi sebuah sistem yang sempurna dan unggul yang akan mengobati ummah dari keterbelakangan nya yang sudah diwarisinya, turuntemurun sejak beberapa abad silam. Dalam Pembelajaran ini siswa tidak hanya diajarkan ilmu dunia tetapi selalu dikaitkan dengan keagungan Ilahi. Dengan sistem ini siswa akan mampu memadukan aktivitas sehari-hari dengan pengajaran di sekolah. Siswa tidak hanya memiliki pengetahuan dengan prestasi yang baik tetapi sekaligus mampu hidup bermasyarakat, dan yang utama mampu menjawab tantangan zaman (Sawaluddin, 2017).

Oleh karena itu, manusia harus didekati dari perspektif persenyawaan antara antroposentris dan teocentris. Artinya proses perkembangan manusia itu didasari nilai Islami yang dialogis terhadap tuntutan Tuhan, tuntutan dinamika sosial dan tuntutan pengembangan fitrah, lebih cenderung kepada pola hidup yang harmonis antara kepentingan dunia dan ukhrawi serta kemampuan belajarnya disemangati oleh misi kekhalifahan dan penghambaan (Maragustam, 2001). Hal ini seirama dengan Pembelajaran agama Islam yang bersifat teosentris dengan konsep antroposentris yang mempunyai bagian esensial dari konsep teosentris (Mastuhu, 1999). Perpaduan inilah yang hendak dicapai dengan Pembelajaran ini. Keterpaduan di sini sesuai dengan prinsip Pembelajaran Islam yang tidak mengenal pemisahan antara sains dan agama 
(prinsip integral dan terpadu). Penyatuan antara kedua sistem Pembelajaran adalah tuntutan akidah Islam (Ramayulis, 2002). Islam adalah religion of nature, segala bentuk dikotomi antara agama dan sains harus dihindari. Alam penuh dengan tanda-tanda, pesan-pesan Ilahi yang menunjukkan kehadiran kesatuan sistem global. Semakin jauh ilmuwan mendalami sains, dia akan memperoleh wisdom berupa philosophic perennis yang dalam filsafat Islam disebut transendence. (Abdurrahman Mas'ud, 2002) Iman tidak bertentangan dengan sains karena iman dan sains sesungguhnya hanya merupakan struggle antara dua kekuatan yang bertikai, yakni konservatif dengan progresif. Kelompok pertama bersifat tertutup, sedangkan yang kedua terbuka. Yang pertama sering memformalkan dan mendogmakan, sedangkan yang kedua mendeformalkan dan mendedogmakan (Abdurrahman Mas'ud, 2002).

Dengan demikian semua cabang ilmu termasuk ilmu agama yang merupakan studi kedua jenis ayat-ayat Allah itu sebenarnya adalah ilmu-ilmu Islami, asalkan disadari dan dilakukan dalam rangka pengembangan pemahaman ilmu pengetahuan, nantinya terdapat ayatayat Allah. Pembelajaran Islam tentu harus mengacu pada ajaran dasar Islam itu sendiri yang tidak memilah-milah antara dunia dan akhirat. Addunya limazra'atil akhirah' dunia adalah ladang penanaman untuk persiapan akhirat, siapa yang menanam akan mendapat, adalah ajaran populer Islam. Doa sapu jagat yang intinya memohon kebahagiaan dunia akhirat juga diucapkan setiap muslim di seluruh dunia (Sawaluddin, et.al, 2018).

Wahyu dan akal tidak dibenarkan terdikotomi dalam Pembelajaran Islam, dengan kata lain, wahyu dan akal atau reason and revelation tidak perlu dipertentangkan dalam Islam, oleh karena itu Pembelajaran Islam tidak dibenarkan adanya dikotomi Pembelajaran yaitu antara Pembelajaran agama dan sains. Peserta didik harus dapat memahami Islam sebagai a total way of life yang dapat mengatur berbagai aspek kehidupan manusia. Kalau dikotomi itu tidak dapat dihindari, minimal seorang pendidik harus dapat melakukan perubahan orientasi mengenal konsep "ilmu" yang secara langsung dikaitkan dengan dalil-dalil keagamaan, atau sebaliknya ajaran agama dikorelasikan dengan ilmu pengetahuan sehingga wawasan anak didik menyatu dalam agama dan ilmu pengetahuan. Oleh karena itu kepada setiap muslim perlu diajarkan ilmu secara utuh, baik mereka yang mengikuti jalur Pembelajaran formal 'dalam madrasah atau jalur nonformal dalam pondok pesantren. Intensitas dan ketinggian tingkat ilmu usul dan kauniah yang diberikan sudah barang tentu bergantung (Sawaluddin Sawaluddin, et.al, 2018).

\section{Prinsip Dasar Evaluasi Pembela jaran Terintegrasi}

Mengingat pentingnya evaluasi dalam menentukan kualitas Pembelajaran, maka upaya merencanakan dan melaksanakan evaluasi hendaknya memperhatikan beberapa prinsip. Menurut Daryanto (2005) , terdapat beberapa prinsip yang perlu diperhatikan dalam melakukan evaluasi, yaitu keterpaduan, keterampilan siswa, koherensi, pedagogis, dan akuntabilitas.

1) Keterpaduan Tujuan instruksional, materi, metode, pengajaran, serta evaluasi merupakan tiga kesatuan terpadu yang tidak boleh dipisahkan. Oleh karena itu, perencanaan evaluasi harus sudah ditetapkan pada waktu menyusun suatu pengajaran sehingga dapat disesuaikan secara harmonis dengan tujuan instruksional dan materi pengajaran yang hendak disajikan.

2) Keterlibatan Siswa Untuk mengetahui sejauh mana siswa berhasil dalam kegiatan belajar mengajar yang dijalani secara aktif, siswa membutuhkan evaluasi. Penyajian 
evaluasi oleh guru merupakan upaya guru untuk memenuhi kebutuhan siswa akan informasi mengenai kemajuannya dalam program belajar mengajar. Siswa akan merasa kecewa apabila usahanya tidak dievaluasi.

3) Koherensi Prinsip evaluasi dimaksud kan evaluasi harus berkaitan dengan materi pengajaran yang sudah disajikan dan sesuai dengan ranah kemampuan yang hendak diukur.

4) Pedagogis Evaluasi dan hasil hendaknya dapat dipakai sebagai alat motivasi untuk siswa dalam kegiatan belajarnya.

5) Akuntabilitas Evaluasi dan hasilnya dapat dipakai sebagai laporan pertanggungjawaban kepada pihakpihak yang berkepentingan dengan Pembelajaran sehingga dapat diketahui sejauh mana keberhasilan pembelajaran yang telah dilakukan. Dalam merencanakan dan melakukan evaluasi pembelajaran, seorang guru hendaknya selalu berpegang pada prinsip-prinsip tersebut. Hal ini dimaksudkan agar guru dapat bertindak dan berusaha seobjektif mungkin dalam mengadakan evaluasi.

Dalam proses pembelajaran, penilaian memegang peranan penting. Informasi yang didapat dari proses penilaian tidak saja penting untuk mengetahui pencapaian tujuan pengajaran dan hasil belajar siswa, tetapi juga untuk mengukur efektifitas kegiatan pembelajaran. Pembelajaran yang dilakukan oleh guru berhubungan dengan pentingnya peranan penilaian dalam dunia Pembelajaran, maka penilaian harus dilakukan dengan baik dan benar. Agar evaluasi dapat terlaksana dengan baik maka diperlukan prinsip sebagai pemandu dalam kegiatan evaluasi. Prinsip-prinsip evaluasi meliputi (Anas Sudijono, 2009) :

a. Prinsip Keseluruhan Prinsip keseluruhan atau prinsip menyeluruh juga dikenal dengan istilah prinsip komprehensif. Dengan prinsip komprehensif dimaksudkan bahwa evaluasi hasil belajar dapat dikatakan terlaksana dengan baik. apabila evaluasi tersebut dilaksanakan secara bulat, utuh, atau menyeluruh.

b. Prinsip kesinambungan Prinsip kesinambungan dikenal dengan istilah prinsip kontinuitas. Dengan prinsip kesinambungan ini dimaksudkan bahwa evaluasi hasil belajar yang baik adalah evaluasi hasil belajar yang dilaksanakan secara teratur dan sambung-menyambung dari waktu ke waktu. Evaluasi hasil belajar yang dilaksanakan secara berkesinambungan ini bertujuan untuk memperoleh kepastian dan kemantapan dalam menentukan langkah-langkah atau merumuskan kebijakan-kebijakan yang perlu diambil untuk masa-masa selanjutnya sebagaimana dirumuskan pada Tujuan Instruksional Khusus (TIK) dapat dicapai dengan sebaik-baiknya.

c. Prinsip Objektivitas Prinsip objektivitas mengandung makna bahwa evaluasi hasil belajar dapat dinyatakan sebagai evaluasi yang baik apabila dapat terlepas dari faktorfaktor yang sifatnya subyektif. Hal ini karena ketika unsur subyektif masuk menyelinap ke dalam kegiatan evaluasi, maka dapat menodai pekerjaan evaluasi itu sendiri. Sedangkan prinsip-prisip evaluasi (penilaian) dalam standar Kurikulum Tingkat Satuan Pembelajaran untuk tingkat dasar dan menengah meliputi sahih (valid), objektif, adil, terpadu, terbuka, menyeluruh dan berkesinambungan, sistematis, menggunakan acuan kriteria, dan akuntabel (Depdiknas, 2012).

\section{Ciri-ciri Evaluasi Pembelajaran Terintegrasi}

Evaluasi hasil belajar memiliki ciri-ciri yang khas yang membedakan dengan bidang kegiatan yang lainnya. 
Ciri-ciri tersebut sebagai berikut(Anas Sudijono, 2009):

a. Evaluasi dilakukan dalam rangka mengukur keberhasilan belajar siswa, di mana pengukurannya dilakukan secara tidak langsung. Guru dapat menggolongkan kemampuan siswanya dengan melakukan evaluasi.

b. Pengukuran dalam rangka menilai hasil belajar siswa pada umumnya menggu nakan ukuran kuantitatif atau dengan simbol-simbol berupa angka. Hasil pengukuran tersebut kemudian dianalisis dengan metode statistik, selanjutnya diinterpretasikansecara kualitatif.

c. Pada kegiatan evaluasi hasil belajar pada umumnya digunakan unitunit atau satuan yang tetap. Penggunaan unit-unit atau satuan yang tetap didasarkan pada teori yang menyatakan bahwa setiap populasi peserta didik yang sifatnya heterogen.

d. Prestasi belajar yang dicapai oleh peserta didik dari waktu ke waktu bersifat relatif. Hasil evaluasi terhadap keberhasilan belajar siswa pada umumnya tidak selalu menunjukkan kesamaan atau keajegan.

e. Kegiatan evaluasi hasil belajar tidak dapat dihindarkan dari kekeliruan pengukuran.

Mengacu dari teori yang dikemukakan oleh Sudijono, ciri-ciri evaluasi hasil belajar dibedakan atas lima, yaitu sebagai berikut.

a. Penilaian dilakukan secara tidak langsung

Maksudnya, jika seorang guru ingin mengetahui mana dari siswanya yang cerdas atau kurang cerdas maka dalam evaluasi yang diukur bukanlah kecerdasan atau kekurangan peserta didik, tetapi indikator atau hal-hal yang menandai bahwa seseorang itu bisa disebut pandai dan kurang pandai. Misalnya, jika seorang dosen/guru ingin mengetahui manakah di antara peserta didiknya yang tergolong pandai, maka yang diukur bukan pandainya tetapi indikator atau hal-hal yang merupakan pertanda bahwa seseorang dapat disebut sebagai orang yang pandai.Carl witherington mengatakan bahwa indikator yang dapat dijadikan kriteria atau tolak ukur untuk menyatakan bahwa seorang peserta didik termasuk kategori pandai adalah bila peserta didik memiliki berbagai kemampuan seperti berikut;

a) Kemampuan untuk bekerja dengan angka-angaka atau bilangan.

b) Kemampuan untuk menggunakan bahasa dengan baik dan benar.

c) Kemampuan untuk menangkap sesuatu yang baru, yaitu dengan secara cepat dapat mengikuti pembicaraan orang lain.

d) Kemampuan untuk mengingat

e) Kemampuan untuk berfantasi atau berfikir secara abstrak

b. Bersifat relatif

Salah satu cirri evaluasi adalah bersifat relative karena nilai seorang siswa tidak selalu konstan dari waktu ke waktu, tetapi bisa saja berubahubah.

c. Bersifat kuantitatif

Dalam evaluasi pembelajaran biasanya dilakukan pengukuran dengan menggunakan simbol bilangan (angka) sebagai hasil untuk pengukurannya. Hasil pengukuran berupa angka-angka ini kemudian dianalisis dan diinterpretasikan kedalam kata-kata (kualitatif).

d. Sering terjadi kesalahan dimana sumber-sumber kesalahan biasanya terletak pada: Alat ukur (soal tes), Pengukur/guru, Yang dinilai (Peserta didik), dan Situasi dimana penilaian berlangsung.

e. Menggunakan satuan unit-unit atau satuan-satuan yang tepat, seperti sangat memuaskan, memuaskan, cukup memuaskan, kurang memusakan, dan tidak memuaskan. 


\section{Ranah Evaluasi Pembelajaran Terintegrasi}

Mengingat bahwa aspek kognitif, aspek afektif dan aspek psikomotor atau ranah kejiwaan itu erat sekali dan bahkan tidak mungkin dapat dilepaskan dari kegiatan atau proses evaluasi hasil belajar, maka dapat dibahas sebagai berikut (Sitti Mania, 2012);

\section{a. Kognitif}

Aspek kognitif adalah aspek yang berkaitan dengan kemampuan berfikir. Menurut teori yang dikemukan oleh Benjamin S. Bloom dkk., segala upaya yan menyangkut aktivitas otak adalah termasuk ranah kognitif. Hasil belajat kognitif adalah prilaku yang terjadi dalam kawasan kognisi, proses belajar yang melibatkan kognisi meliputikegiatan sejak penerimaan stimulus eksteren oleh sensori, penyimpanan pengelolaan dalam otak menjadi informasi hingga pemanggilan kembali untuk menyelesaikan masalah (Sitti Mania, 2012).

$\begin{array}{lcc}\text { Hasil } & \text { belajar kognitif tidak } \\ \text { merupakan } & \text { kemampuan tunggal, } \\ \text { kemampuan } & \text { yang } & \text { menimbulkan } \\ \text { perubahan } & \text { prilaku dalam domain }\end{array}$
kognitif meliputi beberapa jenjang. Banyak klasifikasiyang banyak di buat oleh para psikolog dan Pembelajaran, namun klasifikasi yang banyak digunakan oleh Benyamin S. Bloom yang terdiri dari enam jenjang (Sitti Mania, 2012).

1. Knowledge (Pengetahuan),

Pengetahuan atau ingatan merupakan proses proses berfikir yang rendah. Dalam buku Education Testing and Measurement dikatakan bahwa sasaran level pengetahuan adalah kemampuan siswa mengigat. Pernyataan ini mengadung arti bahwa soal untuk level pengetahuan adalah meminta siswa untuk mengigat kembali atau mengenali fakta, istilah, gejalah dan sebagainya.
2. Comprehension (Pemahaman)

Pemahaman adalah tingkat kemampuan yang mengharapkan peserta didik untuk mampu memahami arti atau konsep, situasi atau fakta yang diketahuinya hal ini peserta didik tidak hanya menghafal secara verbalitas, tapi memahami konsep dari masalah atau fakta yang ditanyakan.

3. Application (Penerapan)

Aplikasi adalah kesanggupan seseorang untuk menerapkan atau mengunakan ide-ide umum, tata cara, metode, prinsip-prinsip, rumus-rumus, teori-teori dan sebagainya dalam situasi baru dan kongkrit.

4. Analysis (Analisi)

Analisis adalah suatu usaha memilah suatu intergrasi (suatu kesatuan) menjadi unsure-unsur atau bagian-bagian sehingga jelas hirarkinya dan atau susunanya. Analisis merupakan kemampuan seseorang untuk merinci suatubahan atau keadaan menurut bagia-bagian yang lebih kecil mampu memahami hubungan yang diantaranya bagianbagian dengan bagian-bagian lainya.

5. Synthesis (Sintesi)

Kemampuan sintesi adalah kemampuan untuk menyatukan unsurunsur atau bagia-bagian ke dalam bentuk menyeluruh. Kemampuan berpikir sintesi ini merupakan kebali kan dari kemampuan berpikir analisi. Berpikir berdasarkan pengetahuan hafalan, berpikir pemahaman, berpikir aplikasi dan berpikir analisi dapat dipandang sebagai berpikir konvergen yang satu tingkat lebih rendah daripada berpikir divergen.

6. Evalution (Evaluasi)

Evalusi merupakan jenjang yang berpikir tertinggi dalam ranah kognitif. Evalusi merupakan kemampuan seseo rang untuk membuat pertimbangan terdapat suatu situasi. Evaluasi adalah memberikan keputasan tentang nilai sesuatu yang mungkin dilihat dari segi tujuan, 
gagasan, cara bekerja, pemahaman, metode, materi dan lain-lainya.

Tujuan aspek kognitif berorientasi pada kemampuan berfikir yang mencakup kemampuan intelektual yang lebih sederhana, yaitu mengingat, sampai pada kemampuan memecahkan masalah yang menuntut siswa untuk menghubungkan dan menggabungkan beberapa ide, gagasan, metode atau prosedur yang dipelajari untuk memecahkan masalah tersebut. Dengan demikian aspek kognitif adalah subtaksonomi yang mengungkapkan tentang kegiatan mental yang sering berawal dari tingkat pengetahuan sampai ke tingkat yang paling tinggi yaitu evaluasi. Evaluasi hasil belajar kognitif dapat dilakukan dengan menggunakan tes objektif maupun tes uraian.

\section{b. Ranah Afektif}

Ranah afektif yang berkenaan dengan sikap dan nilai. Beberapa ahli mengatakan sikap seseorang dapat diramalkan perubahanya. Bila seseorang telah memiliki penguasaan tingkat kognitif tingkat tinggi.penilaian hasil belajar afektif kurang mendapatkan perhatian dari guru. Para guru hanya menilai ranah kognitif semata-mata. Ada beberapa jenis ranah afektif sebagai hasil belajar kategorinya dimulai dari tingkat yang paling mendasar atau sederhana sampai tingkat yang kompleks (Nana Sudjana, 2009).

\section{Reciving/attending}

Yakni semacam kepekaan dalam menerima (stimulus) dari luar yang dating keepada siswa dalam bentuk masalah, situasi, gejala, dll. Dalam tipe ini termasuk kesadaran, keinginan, untuk menerima stimulus, kontrol, dan seleksi gejala atau ransangan dari luar. Termasuk dalam jenjang ini misalnya adalah: kesadaran dan keinginan untuk menerima stimulus, mengontrol dan menyeleksi gejala-gejala atau rangsangan yang datang dari luar. Receiving atau attenting juga sering di beri pengertian sebagai kemauan untuk memperhatikan suatu kegiatan atau suatu objek. Pada jenjang ini peserta didik dibina agar mereka bersedia menerima nilai atau nilai-nilai yang di ajarkan kepada mereka, dan mereka mau menggabungkan diri kedalam nilai itu atau meng-identifikasikan diri dengan nilai itu. Contah hasil belajar afektif jenjang receiving, misalnya: peserta didik bahwa disiplin wajib di tegakkan, sifat malas dan tidak di siplin harus disingkirkan jauh-jauh.

2. Responding/jawaban

Yakni reaksi yang diberikan oleh seseorang terhadap stimulus yang dating dari luar. Hal ini mencakup ketepatan reaksi, perasaan, kepuasan dalam menjawab stimulus dari luar yang datang pada dirinya. Jadi kemampuan menanggapi adalah kemampuan yang dimiliki oleh seseorang untuk mengikut sertakan dirinya secara aktif dalam fenomena tertentu dan membuat reaksi terhadapnya salah satu cara. Jenjang ini lebih tinggi daripada jenjang receiving. Contoh hasil belajar ranah afektif responding adalah peserta didik tumbuh hasratnya untuk mempelajarinya lebih jauh atau menggeli lebih dalam lagi, ajaranajaran Islam tentang kedisiplinan.

3. Valuing (penilaian)

Berkenaan nilai dan kepercayaan terhadap gejala atau stimulus tadi. Dalam evaluasi ini termasuk di dalamnya kesediaan menerima nilai, latar belakang, atau pengalaman untuk menerima nilai kesepakatan terhadap nilai tersebut. Menilai atau menghargai artinya mem-berikan nilai atau memberikan penghargaan terhadap suatu kegiatan atau obyek, sehingga apabila kegiatan itu tidak dikerjakan, dirasakan akan membawa kerugian atau penyesalan. Valuing adalah merupakan tingkat afektif yang lebih tinggi lagi daripada receiving dan responding. Dalam kaitan dalam 
proses belajar mengajar, peserta didik disini tidak hanya mau menerima nilai yang diajarkan tetapi mereka telah berkemampuan untuk menilai konsep atau fenomena, yaitu baik atau buruk. Bila suatu ajaran yang telah mampu mereka nilai dan mampu untuk mengatakan "itu adalah baik", maka ini berarti bahwa peserta didik telah menjalani proses penilaian. Nilai itu mulai di camkan (internalized) dalam dirinya.

4. Organisasi

Yakni mengembangkan dari nilai ke dalam suatu sistem organisasi, termasuk hubungan satu nilai dengan nilai lain, pemantapan dan prioritas nilai yang telah dimilikinya. Yang termasuk ke dalam organisasi ialah konsep tentang nilai, organisasi sistem nilai, dll. Mengatur atau mengorgani sasikan merupakan pengembangan dari nilai kedalam satu sistem organisasi, termasuk didalamnya hubungan satu nilai denagan nilai lain., pemantapan dan perioritas nilai yang telah dimilikinya.

5. Karakteristik nilai atau interalisasi tentang nilai.

Yakni keterpaduan tentang sistem nilai yang telah dimiliki seseorang, yang mempengaruhi pola kepribadian dan tingkah lakunya. Ke dalamnya termasuk keseluruhan nilai dan karakteristiknya. Disini proses internalisasi nilai telah menempati tempat tertinggi dalal suatu hirarki nilai. Nilai itu telah tertanam secara konsisten pada sistemnya dan telah mempengaruhi emosinya. Ini adalah merupakan tingkat efektif tertinggi, karena sikap batin peserta didik telah benar-benar bijaksana. Ia telah memiliki phyloshopphy of life yang mapan. Jadi pada jenjang ini peserta didik telah memiliki sistem nilai yang telah mengontrol tingkah lakunya untuk suatu waktu yang lama, sehingga membentu karakteristik "pola hidup" tingkah lakunya menetap, konsisten dan dapat diramalkan. Secara skematik kelima jenjang afektif sebagaimana telah di kemukakan dalam pembicaraan diatas, menurut A.J Nitko (1983) dapat di gambarkan sebagai berikut: "Ranah afektif tidak dapat diukur seperti halnya ranah kognitif, karena dalam ranah afektif kemampuan yang diukur adalah: Menerima (memperhatikan), Merespon, Menghargai, Mengorgani sasi, dan Karakteristik suatu nilai.

Skala yang digunakan untuk mengukur ranah afektif seseorang terhadap kegiatan suatu objek diantaranya skala sikap. Hasilnya berupa kategori sikap, yakni mendukung (positif), menolak (negatif), dan netral. Sikap pada hakikatnya adalah kecenderungan berperilaku pada seseorang. Ada tiga komponen sikap, yakni kognisi, afeksi, dan konasi. Kognisi berkenaan dengan pengetahuan seseorang tentang objek yang dihadapinya. Afeksi berkenaan dengan perasaan dalam menanggapi objek tersebut, sedangkan konasi berkenaan dengan kecenderungan berbuat terhadap objek tersebut.

Tujuan dilaksanakannya penilaian hasil relajar afektif ádalah untuk mengetahui capaian hasil belajar dalam hal penguasaan domain afektif dari kompetensi yang diharapkan dikuasai oleh setiap peserta didik setelah kegiatan pembelajaran berlangsung. Teknik pengukuran dan penilaian hasil belajar afektif terdiri atas dua yakni teknik testing, yaitu penilaian yang menggunakan tes sebagai alat ukurnya, dan teknik nontesting, yaitu teknik penilaian yang menggunakan bukan tes sebagai alat ukurnya.

\section{c. Ranah Psikomotorik}

ranah $\begin{array}{cr}\text { Ranah psikomotor merupakan } \\ \text { yang berkaitan dengan }\end{array}$ keterampilan (skill) atau kemampuan bertindak setelah seseorang menerima 
pengalaman belajar tertentu. Ranah psikomotor adalah ranah yang berhubungan dengan aktivitas fisik, misalnya lari, melompat, melukis, menari, memukul, dan sebagainya. Hasil belajar ranah psikomotor dikemukakan oleh Simpson (1956) yang menyatakan bahwa hasil belajar psikomotor ini tampak dalam bentuk keterampilan (skill) dan kemampuan bertindak individu. Hasil belajar psikomotor ini sebenarnya merupakan kelanjutan dari hasil belajar kognitif (memahami sesuatu) dan hasil belajar afektif (yang baru tampak dalam bentuk kecenderungan-kecenderungan berperilaku). Hasi belajar kognitif dan hasil belajar afektif akan menjadi hasil belajar psikomotor apabila peserta didik telah menunjukkan perilaku atau perbuatan tertentu sesuai dengan makna yang terkandung dalam ranah kognitif dan ranah afektif dengan materi kedisiplinan menurut agama Islam.

Hasil belajar psikomotorik tampak dalam bentuk keterampilan (skill) dan kemampuan bertindak individu. Ada enam tingkat keterampilan, yakni (Nana Sudjana, 2009):

a) Gerakan refleks (keterampilan pada gerakan yang tidak sadar)

b) Keterampilan pada gerakan-gerakan dasar

c) Kemampuan spiritual, termasuk di dalamnya membedakan visual, membedakan auditif, motoris, dan lain-lain.

d) Kemampuan di bidang fisik, misalnya kekuatan, keharmonisan dan ketepatan.

e) Geraka-gerakan skill, mulai dari keterampilan sederhana sampai pada keterampilan yang kompleks.

f) Kemampuan yang berkenaan dengan komunikasi non-decursive seperti gerakan ekspresif dan interpretative.

Dalam penilaian hasil belajar psikomotor atau keterampilan harus mencakup persiapan, proses, dan produk. Penilaian dapat dilakukan pada saat proses berlangsung yaitu pada waktu peserta didik melakukan praktik, atau sesudah proses berlangsung dengan cara mengetes peserta didik.Penilaian psikomotorik dapat dilakukan dengan menggunakan observasi atau pengamatan. Dengan kata lain, observasi dapat mengukur atau menilai hasil dan proses belajar atau psikomotorik. Misalnya tingkah laku peserta didik ketika praktik,kegiatan diskusi peserta didik, partisipasi peserta didik dalam simulasi, dan penggunaan alins ketika belajar. Tes untuk mengukur ranah psikomotorik adalah tes untuk mengukur penampilan atau kinerja (performance) yang telah dikuasai oleh peserta didik.

\section{KESIMPULAN}

Evaluasi Pembelajaran Terintegrasi merupakan kegiatan untuk menilai sesuatu secara terencana, sistematik, dan terarah berdasarkan tujuan yang jelas dengan menggabungkan sejumlah disiplin keilmuan melalui penentuan isi (content), kemampuan, dan tujuan afektif. Adapun Prinsip Dasar Evaluasi Pembelajaran Terintegrasi, yaitu keterpaduan, keterampilan siswa, koherensi, pedagogis, dan akuntabilitas. Sedangkan Ciri-ciri Evaluasi Pembelajaran Terintegrasi yaitu, Evaluasi dilakukan dalam rangka mengukur keberhasilan belajar siswa, di mana pengukurannya dilakukan secara tidak langsung. Sementara Ranah Evaluasi Pembelajaran Terintegrasi, yakni aspek kognitif, aspek afektif dan aspek psikomotor

REFERENSI

Abdurrahman Mas'ud, Menggagas Format Pembelajaran Non dikotomik, Yogyakarta: Gama Media, 2002

Anas Sudijono, "Pengantar Evaluasi Pembelajaran", Jakarta : PT Rajagrafindo Persada, 2011

Daryanto, Evaluasi Pembelajaran. Jakarta : Rineka Cipta, 2005

Depdiknas."RancanganPenilaian hasil Belajar KTSP SMA", dalam http://. www.dikmenum.go.id /perangkat 
penilaian KTSP diakses 16 Januari 2012

Fazlur Rahman, Islam dan Modernitas: Tantangan Transformasi Intelektual, (Terj. Ahsi Muhammad), Bandung: Pustaka, 2000

Hanna Djumhana Bastaman, Integrasi Psikologi Dengan Islam: Menuju Psikologi Islami, Yogjakarta: Pustaka Pelajar Bekerjasama dengan Yayasan Insan Kamil, 2003, cet.III

Hilmy Bakar Almascaty, Membangun Kembali Sistem Pembelajaran Kaum Muslimin, Jakarta: Universitas Islam Azzahro Press, 2000

Ikhrom, Dikhotomi Sistem Pembelajaran Islam, dalam Ismail SM (eds), Paradigma Pembelajaran Islam, Yogyakarta: Pustaka Pelajar, 2001.

Maragustam, Revitalisasi Strategi Pembelajaran Pembelajaran Agama Islam Menapaki Abad Modern, Fakultas Tarbiyah IAIN Sunan Kalijaga, Jurnal Ilmiah Pembelajaran Islam, Vol. 2. No. I, Juli 2001.

Mastuhu, Memberdayakan Sistem Pembelajaran Islam, Jakarta: Logos, 1999, cet II

Muh. Faisal, Pembelajaran Terpadu, dalam Ekspose Penelitian Hukum dan Pembelajaran, Jurnal STAIN Watampone, 2001 ISSN: 1412

Muhammad Numan Soemantri, Menggagas Pembaharuan Pembelajaran IPS, (Bandung: PT. Remaja Rosda Karya, 2001

Moh.Kasiram, Pendidikan Sains Terpadu Sebagai Akselelator Kebangkitan Sains Islam, Jurnal STAIN Malang, No. 6, Tahun 1999 ISSN: 14100592

Nana Sudjana, Penilaian Hasil Proses Belajar Mengajar Cet. XIII; Bandung: PT Rosdakarya Offiset, 2009, hlm, 30.
Nurcholis Madjid, Islam Doktrin dan Peradaban, Jakarta: Paramadina, 1992

Oemar Hamalik, Pendekatan Baru Srategi Belajar Mengajar Berdasarkan CBSA, Bandung : Sinar Baru Algensindo, 2012.

Ramayulis, Ilmu Pendidkan Islam, Jakarta: Kalam Mulia, 2002 cet.II

Sawaluddin Sawaluddin, Koy Sahbuddin Harahap, Muhammad Syaifuddin, Sainab Sainab, Syahrul Akmal Latif, Development of the Potential Senses, Reason, and Heart According to the Qur'an and its Application in Learning, Advances in Social Science, Education and Humanities Research, volume 253, 3rd Asian Education Symposium AES 2018

Sawaluddin, "Konsep Evaluasi Dalam Pembelajaran Pembelajaran Islam." Jurnal Pembelajaran Agama Islam AlThariqah 3, No. 1 July 13, 2018

Sawaluddin, dan Muhammad Siddiq, Langkah-Langkah Dan Teknik Evaluasi Hasil Belajar Pembelajaran Agama Islam. Jurnal PTK \& Pendidika, 2020. vol 6. No 1

Sawaluddin, Koy Sahbudin Harahap, Supardi Ritonga, Muhammad Ramli, Prosedur Pengembangan Evaluasi Pembelajaran Pembelajaran Agama Islam, Jurnal Pembelajaran Islam Vol. 8 No.3 Januari - Juni 2020

Sawaluddin, Munzir Hitami, Zikri Darussamin, Sainab, The Potential of the Senses in AlQuran as the Basic Elements of the Human Physic and Its Application in Learning, Advances in Social Science, Education and Humanities Research, volume 261, International Conference on Islamic Education ICIE 2018.

Sawaluddin, Potensi Indra, Akal, dan Kalbu Menurut Al-Qur'an dan 
Journal of Islamic Education El Madani

Volume 1. Nomer 1. Desember 2021

Aplikasinya Dalam Pengembangan Pembelajaran Dasar, Pekanbaru: UIN Suska Riau, Disertasi, 2017

Sawaluddin, Sainab, The Intelligent Meaning In The Qur'an: Nalysis of The Sure Potential In The AlQur'an As A Dimension Of Human Psychic Insaniah, Jurnal Madania: Volume $9: 2,2019$

Sitti Mania, Pengantar Evaluasi Pembelajaran Makassar: Alauddin University Press, 2012. 